\title{
Eco- friendly strategies for management of Fusarium wilt of Pisum sativum L.
}

\author{
Shashi Kapoor, Ashish Jaiswal and D.N. Shukla \\ Bhargava Agriculture Laboratory, Department of Botany, University of Allahabad, Allahabad 211002, India.
}

Accepted 6 July, 2010

\begin{abstract}
The efficacy of different microbes for their antagonistic ability was determined in-vitro against Fusarium oxysporum f. sp pisi by dual culture method. T. viride and Pseudomonas fluorescens-I exhibited maximum antagonistic activity in vitro. In-vivo $T$. viride and Pseudomonas fluorescens resulted in maximum reduction of seed rot root and wilt (Fusarium oxysporum) of pea. In addition, there was increased germination, mortality, shoot length, root length, fresh weight, vigour index and numbers of nodules. Among the microbes, $T$. viride performed better. Therefore, $T$. viride may be used for the reduction of root rot, wilt and mortality of pea.
\end{abstract}

Key words: Fusarium wilt, pea, bioagent, control.

\section{INTRODUCTION}

Pea (Pisum sativum) is one of the most important cash crops for farmers of Uttar Pradesh. It is attacked by several disease caused by fungi, bacteria and viruses. Among these diseases, wilt caused by Fusarium oxysporum schl. f. sp. pisi Synder and Hansen is the most destructive disease of the crop and occurs as an epiphyte almost every year. The disease is essentially soil borne and poses a greater problem in management by using fungicides which are uneconomical and their frequent and indiscriminate use often leads to atmospheric pollution and development of resistance in the pathogens. In this context, biological control is an alternative strategy of disease management which is ecofriendly. Several organisms have been successfully used as biocontrol agents, such as the species of Trichoderma (Raguchander et al., 1997), Pseudomonas, Gliocladium Penicillium (Castejón-Muñoz and Oyarzun, 1995), Rhizobium (Bradshaw et al., 1991), etc. Based on the review of literature, it appeared that biological seed treatment was feasible and attempts were made in the present study to select effective antagonists and biofertilizers which could be applied to pea seeds. These were evaluated by laboratory and field condition.

\footnotetext{
*Corresponding author. E-mail: ashish_botany@yahoo.com.
}

\section{MATERIALS AND METHODS}

The soil samples were collected from pea growing areas of Allahabad (U.P.) in polythene bags. The samples were taken from the rhizosphere of healthy pea plant, pooled and then isolation of associated microbiota was made by dilution plate method (Waksman, 1916). The culture was identified on the basis of morphological characters documented in taxonomic key (Von Arx, 1978).

In vitro study

Antagonistic potential of the isolated soil microflora and those in laboratory collection against $F$. oxysporum was detected by dual culture technique on potato dextrose agar (PDA) medium with three replications for each isolates and control. They were incubated for 7 days at $24 \pm 1^{\circ} \mathrm{C}$.

\section{In vivo study}

This study was conducted in poly house of the department of Botany, University of Allahabad (2007 - 2008). Inoculum of $F$. oxysporum was prepared following the method of Dutt and Das 2002. Soil was mixed uniformly with cow dung (2:1). The dried soil was sterilized with formalin $40 \% ; 5 \mathrm{ml}$ formalin diluted with $20 \mathrm{ml}$ of water for $4 \mathrm{~kg}$ soil at $0.1 \%$ weight of dry soil (Haque et al., 1995; Harnadez and Hill, 1983). The culture of $F$. oxysporum was then mixed with pot soil before seed showing (Chunje and Zhibiao, 1996; Gomez and Gomez, 1984).

The inoculum was applied only up to a depth of $6 \mathrm{~cm}$ in pot soils 
Table 1. In vitro evaluations of antagonists against F.oxysporum f. sp. Pisi.

\begin{tabular}{lcc}
\hline Antagonist & Inhibition (\%) & Zone of inhibition (+) interaction (-) \\
\hline T. viride & 51.55 & - \\
T. harzianum & 34.55 & - \\
Pseudomonas fluarescens-1 & 49.62 & - \\
Pseudomonas fluarescens-2 & 50.08 & + \\
Aspergillus niger & 27.36 & - \\
Gliocladium virens & 26.39 & - \\
Rhizobium strain-1 & 34.55 & - \\
Rhizobium strain-2 & 32.28 & - \\
CD 70.05 & $(1.059)$ & \\
\hline
\end{tabular}

Data represent the means of three replications.

that were $2 \mathrm{~g}$. Culture of $F$. oxysporum was mixed with each pot soil. A total of 20 pots were inoculated without culture for three replications. Seed were counted, weight and packed in separate polyethylene bags as per treatment and replication. 2Trichoderma strains, 2 Pseudomonas strains 1 Gliocladium virens, 1 Aspergillus niger and two biofertilizers (Rizobium-1 and Rizobium-2) were used for treating seed. Seeds were treated with selected antagonist strains and biofertilizers following the methods of earlier researchers (Das, 1988; Harnadez and Hiill, 1983; Hassain and Mohammed, 2002; Hassain, 2000).

For seed coating, selected antagonistic strains containing $2 \times 10^{7}$ $\mathrm{cfu} / \mathrm{ml}$ spore suspension seed treatment as liquid formulation was used. The seeds were dipped in the broth for $15 \mathrm{~min}$. In the case of biofertilizers, seed were initially moistened with molasses at $50 \mathrm{~g}$ per $\mathrm{kg}$ seed. Then seeds were thoroughly mixed with biofertilizers (50 g/kg seed). Each biofertilizer contained $3 \times 10^{9}$ rhizobium cells/mg. In the control, seeds were not treated with selective antagonist strains or biofertilizers. The inoculants coated seed were placed in a cool and dry place under shade for drying. Treated seeds and non treated seeds for control were sown in previous prepared soil in pots. 5 seeds were sown in each pot. Observation was made every day in the morning on root rot and wilt infected plants. Interculture operations were done to maintain normal hygienic condition of crop growth. No plant protecting chemicals (insecticides and fungicides) were used for control of pests and diseases of crop. Data were recorded for germination seed rot, root rot, wilt plant, stand seedling vigour, number of nodules per plant, number of green pods per plant and plant height for vigour index. Data were recorded for germination up to the15th day of sowing. 5 plants were randomly selected, uprooted carefully from pot and washed in tap water. Then, root length and shoot length were recorded. Vigour index was calculated by the formula of Baki and Anderson (1973) as shown below:

Vigour index $=$ Mean shoot length + mean root length) $\times$ Germination (\%)

The data were subjected to statistical analysis for mean values and test of significance.

\section{RESULTS AND DISCUSSION}

The data (Table 1) indicate that all the antagonists inhibited the mycelial growth of $F$. oxysporum f. sp. Pisi. T. viride (51.55), $P$. fluorescens-1 (49.62) and $P$. fluorescens -2 (50.08) showed maximum inhibition and were statistically different. These were significantly higher than other antagonists such as rhizobium-1 (34.55) and rhizobium -2 (32.28). However T. hamatum (35.55), Gliocladium virens and Aspergillus niger (27.36) were found least effective. The zone of inhibition was observed only in Pseudomonas fluorescens-2 whereas, other treatment revealed zone of interaction. The inhibitory effect of Trichoderma spp. against F. oxysporum f. sp pisi was probably due to hyperparasitism, mycoparasitism, competition for space and nutritional sources and antagonistic chemicals produced and released into the environment. Trichoderma spp. has been reported to produce antibiotic compound (Trichodermin), extracellular enzymes (chitinase, cellulose), unsaturated monobasic acid and peptides (Alamethicine) that either damage plant pathogens or enhance their population in maintaining favorable balance as a portion of the biota (Mukherji and Garg, 1988). Trichoderma spp. has also been employed in biological control of disease of vegetable crops caused by soil borne plant pathogens (Baker and Cook, 1974; Chet, 1987; Chet and Baker, 1981; Elad et al., 1980).

\section{In vivo evaluation}

Germination seed rot, wilt and plant stand were significantly affected by antagonist and biofertilizers (Table 2). The highest germination (93.25) were recorded when seeds were treated with $T$. viride which was statistically similar to $P$. fluorescens- 1 (90.75). The lowest seed germination (72.33) was recorded in the control. The highest seed rot $(27.65)$ was observed in control, while the lowest $(6.75 \%)$ in $T$. viride followed by $P$. fluorescens-1 $(9.25 \%)$. The highest wilt $(48.65 \%)$ was observed in control and the lowest wilt $(8.49 \%)$ in $T$. viride which was statistically similar to $P$. fluorescens- 1 (1.56). Maximum plant stand (91.51\%) was recorded in $T$. viride which was statistically similar to $P$. fluorescens- 1 (88.44). The lowest plant stand (51.35) was recorded in untreated control. Shoot length, root length, fresh weight, 
Table 2. Effect of biocontrol agents on seed germination, seed rot and wilt of Pea in pot condition.

\begin{tabular}{lcccc}
\hline Antagonist biofertilizers & Germination (\%) & Seed rot (\%) & Wilt (\%) & Plant stant (\%) \\
\hline T. viride & 93.25 & 6.75 & 8.49 & 91.51 \\
T. harzianum & 79.90 & 20.10 & 25.34 & 74.66 \\
Pseudomonas fluorescens-1 & 90.75 & 9.25 & 11.56 & 88.44 \\
Pseudomonas fluorescens-2 & 81.39 & 18.61 & 24.76 & 75.24 \\
Gliocladium virens & 83.95 & 16.05 & 17.34 & 82.66 \\
Rhizobium-2 & 87.69 & 12.31 & 13.86 & 86.14 \\
Rhizobium-1 & 82.88 & 17.12 & 20.01 & 79.99 \\
Aspergillus niger & 86.11 & 13.89 & 15.70 & 84.30 \\
Control & 72.33 & 27.67 & 48.65 & 51.35 \\
CD (P>0.01) & 5.084 & 5.084 & 4.081 & 4.084 \\
\hline
\end{tabular}

Data represent the means of three replications.

Table 3. Effect of seed treatment with antagonist and biofertilizer on plant (growth of pea in Fusarium oxysporum f.sp. pisi infested in pot).

\begin{tabular}{lcccccc}
\hline Antagonist and biofertilizer & $\begin{array}{c}\text { Shoot length } \\
\text { plant } \mathbf{( c m )}\end{array}$ & $\begin{array}{c}\text { Root length } \\
\text { plant } \mathbf{( c m )}\end{array}$ & $\begin{array}{c}\text { Fresh Wt } \\
\mathbf{( g )}\end{array}$ & $\begin{array}{c}\text { Nodules/ } \\
\text { plant }\end{array}$ & $\begin{array}{c}\text { Seedling } \\
\text { vigour }\end{array}$ & $\begin{array}{c}\text { Mortality } \\
\text { (\%) }\end{array}$ \\
\hline T. viride & 20.5 & 31.3 & 4.1 & 72.7 & 5030.3 & 3.3 \\
T. harzianum & 17.4 & 22.1 & 2.6 & 21.3 & 3422.6 & 16.7 \\
Pseudomonas fluorescens-1 & 20.0 & 28.1 & 4.0 & 56.0 & 4328.1 & 6.7 \\
Pseudomonas fluorescens-2 & 16.4 & 20.7 & 2.6 & 32.7 & 2637.5 & 26.7 \\
Gliocladium virens & 18.8 & 23.1 & 2.5 & 28.0 & 3763.8 & 10.0 \\
Rhizobium -1 & 15.8 & 26.2 & 4.1 & 75.7 & 4206.0 & 10.0 \\
Rhizobium -2 & 16.1 & 23.4 & 2.5 & 31.3 & 3427.8 & 16.7 \\
Aspergillus niger & 18.2 & 24.7 & 3.2 & 12.7 & 3570.7 & 16.7 \\
Control & 10.5 & 7.5 & 1.2 & 8.0 & 718.0 & 73.3 \\
CD $(\mathrm{P}=0.05)$ & 2.9 & 4.0 & 1.1 & 18.9 & 910.4 & 10.6 \\
\hline
\end{tabular}

number of nodules per plant, seedling vigour and mortality percentages were significantly influenced by the antagonist and biofertilizers (Table 3). The highest shoot length $(20.5 \mathrm{~cm})$ was noted in the seed treated with $T$. viride which was statistically similar to $P$. fluorescens$1(20.0 \mathrm{~cm})$ and followed by $G$. virens (18.8), A. niger (18.2), T. harzianum (17.4) and $P$. fluorescens-2 (16.4). Rhizobium S-2 (16.1) and Rhizobium S-1 (15.8) untreated control produced the lowest shoot length (10.5 $\mathrm{cm})$. Though the treatments did not show any significant effect on root length it ranged from $(7.50 \mathrm{~cm})$ control to $(31.3 \mathrm{~cm})$. In all treatment the highest fresh weight per plant was $4.1 \mathrm{~g}$ in $T$. viride which was statistically similar to Rhizobium S-1 $(4.1 \mathrm{~g})$, Pseudomonas fluorescens (4.0 $\mathrm{g})$, A. niger (3.2 g), T. harzianum $(2.6 \mathrm{~g})$ and $G$. virens $(2.5 \mathrm{~g})$. Higher vigour index of seedling (5030.3) was obtained from $T$. viride and the lowest (718.8) was in untreated control. Maximum number of nodules per plant (757) was observed in Rhizobium $S$-1 which was statistically similar to $T$. viride (72.2) and the lowest (8.0) in untreated control. The lowest mortality (3.3\%) was observed in $T$. viride and the highest mortality percentage was observed in the untreated control (73.3\%) Table 3.
Chakrobarty and Chakraborty (1989) reported that bacterization of seed with Rhizobium leguminosorum biovar viceae was highly effective in reducing the severity of food rot in Pea caused by Fusarium solani f. sp pisi, while Perveen and Ghaffar (1991) reported that Rhizobium meliloti gave complete control of Fusarium oxysporum on 30 days and 120 days old tomato plant with higher seed germination as compared with untreated control. Pseudomonas has been reported to improve plant growth parameter and suppress the attack of different pathogens and diseases caused by them leading ultimately to improved crop yield (kloepper et al., 1986; Davision, 1988; Jeon et al., 2003). Effectiveness of $T$. koningi, $T$. viride, Gliocladium catenulatum and $G$. raseum against pea root rot complex was demonstrated by Lacicowa and Pjeta (1994).

\section{REFERENCES}

Baker FK, Cook RJ (1974). Biological control of plant pathogens W.H. Freeman and Comp. San Francisco 433 pp.

Baki AA, Anderson JD (1973). Vigour determination in soybean by multiple criteria. Crop Sci. 13:630-633. 
Castejón-Muñoz M, Oyarzun PJ (1995). Soil receptivity to Fusarium solanif. spp. pisi and biological control of root rot of Pea. Eur. J. Plant Pathol. ss101:35-49.

Chakrobarty U, Chakhrobarty DN (1989). Interaction of Rhizobium leguminosarum and Fusarium solani f. sp. pisi on pea affecting disease development and phytoalexin production. Can. J. Bot. 67(6):1698-1701.

Chet I (1987). Innovative approaches to plant disease control. Johan Wiley. New York.

Chet I, Baker R (1981). Isolation and bio-control potential of Trichoderma hamatum from soil naturally suppressive to Rhizoctonia solani. Phytopathology 71:286-290.

Chunje L, Zhigiao N (1996). Occurrence and damage of food rot in spring broad bean in Linxia area. Plant prot. 22(6):25-26.

Dutt P, Das DC (2002). Managment of collar rot of Potato by Trichoderma spp. and chemicals. Indian Phytopathol. 55(20):238237.

Elad Y, Chet I, Katan J (1980). Trichoderma harzianum. A biocontrol agent effective against sclerotium roftsii and Rhizoctonia solani. Phytopathology 70:119-121.

Gomez KA, Gomez AA (1984). Statistical procedures for Agriculture research, International. Rice Research. Institute. John wiley and Sons, New York, Chikester, Brisbone, Torento, Singapore. p. 643.

Haque SE, Abid M, Ghaffar A (1995). Efficacy of Bradyrhizobium sp and paecilomyces lilacinus with oil cakes in the control of root rot of mungbean. Tropscal Sci. 53(3):294-299.

Harnadez LG, Hill GD (1983). Effect of plant population and inoculation on yield and yield component of chickpea. Agraon Soc. New Zealand 13:75-79.

Hassain I (2000). Biocontrol of Fusarium oxysporum and Scleratium rolfsii infection in lentil, chickpea and mungbeen. BAU Res. Prog. $11: 61$.
Hassain J, Mohammed D (2002). Seed treatment with biofertilizor in controlling disease of mungbean. BAU. Prog. 12:34.

Jeon JS, Lee SS, Kim HY, Ahn TS, Song HG (2003). Plant growth promotion in soil by some inoculated microorganisms. J. Microbiol. 41:271-276.

Kloepper JW, Scher FM, Laliberti M, Tipping B (1986). Emergency promoting bacteria description and implication for agriculture. In Iron Siderophore and plant diseases. Swinburne, T.R. (ed.) Plamun, New York USA. pp. 155-164.

Lacicowa B, Pjeta D (1994). Protective effect of microbiological dressing of pea seeds (Pisum sativum) against pathogenic fungi living in soilAnnales universitatis Mariaccurie-Sklodowska- Satio- EEEHorticulture. 2:165-171.

Mukherji KG, Garg KL (1988). Biocontrol of plant diseases vol. 1 RC press Inc. Florida. $211 \mathrm{pp}$.

Perveen S, Ghaffar A (1991). Effect of microbial antagonists in the control of root rot of tomato. Pak. J. Bot. 23(2): 179-182.

Raguchander T, Rajappan K, Samiappan R (1997). Evaluating methods of application of bio-control agent in the control of mungbean root rot. Indian phytopathol. 50:229-234.

Von Arx JA (1978). The genera of fungi sporulating in pure culture. In A.R. Gantner and K.G. Verlag, (eds.). FL-9490 Vaduz. Liechtenstein. $315 \mathrm{p}$.

Waksman SA (1916). Do fungi live and produce mycelium in the soil. Sci. N.S., 44:320-322. 